\title{
Kesulitan Mahasiswa Dalam Mengkoneksikan Sigma, Area, dan Definisi Integral Tentu Secara Geometri
}

\author{
Fridgo Tasman ${ }^{1)}$ Defri Ahmad $^{1)}$ Suherman $^{1)}$ \\ ${ }^{1)}$ Staf Pengajar Jurusan Matematika, FMIPA Universitas Negeri Padang \\ fridgo_tasman@fmipa.unp.ac.id
}

\begin{abstract}
Integral is one of major topics in Calculus course. Many university students fail in calculus course because their understanding on the concept of Integral especially in understanding definition of integral is low. This situation encourages us to design a calculus lesson to build students understanding on Integral especially integral definition by using Realistic Mathematics Education as an approach. For that, we try to design a series of instructional activities starting from introducing sigma to definition of Integral in order to know students difficulties in understanding this topic. Some first-year university students in Universitas Negeri Padang are chosen to test our Hypothetical Learning Trajectory (HLT) in our preliminary research. The result is students had difficulties in connecting the sigma, area and definition of integral. This happens because the students did not see that the activities that have been designed as a whole that cannot be separated. Therefore, it is recommended to design a series of instructional activities which is focus on connecting sigma, area and definition of integral.
\end{abstract}

Keywords : Design Research, Integral, Realistic Mathematics Education

\section{PENDAHULUAN}

Integral merupakan salah satu dari tiga topik utama yang di bahas dalam mata kuliah kalkulus(Zakaria, Effandi \& Salleh, 2016). Akan tetapi banyak penelitian yang menyatakan bahwa para mahasiswa masih mengalami kesulitan dalam topik ini (Mahir, 2009). Hal ini, juga terjadi di Universitas Negeri Padang (UNP), dimana pada umumnya banyak mahasiswa yang gagal dalam mata kuliah ini dan lulus dengan nilai yang kurang me-muaskan(Tasman \& Ahmad, 2017). Jika hal ini terus dibiarkan maka hal ini akan berdampak kepada kesuksesan mahasiswa dalam perku-liahan. Terlebih lagi kalkulus merupakan mata kuliah dasar bagi mahasiswa jurusan matematika sehingga ia menjadi pondasi bagi mata kuliah lanjutan.

Ketika mahasiswa belajar tentang integral, mereka diharapkan telah memahami tentang jumlah Riemann, limit, dan luas (Serhan, 2015). Mahasiswa harus mampu menghubungkan konsep-konsep tersebut dengan baik guna membangun pemahaman tentang integral. Akan tetapi, (Tasman \& Ahmad, 2018) menemukan dalam penelitiannya bahwa pada umumnya mahasiswa belum mampu menguasai tentang konsep-konsep tersebut dengan baik. Mereka membutuhkan waktu untuk yang lebih banyak untuk bereksplorasi dalam memecahkan masalah-masalah tentang jumlah Riemann, limit dan luas. Hal ini menjadi suatu masalah karena padatnya materi dalam mata kuliah kalkulus sehingga mahasiswa tidak mempunyai cukup waktu untuk bereksplorasi.

Berdasarkan situasi ini, maka dirasakan pentingnya untuk mendesain suatu rangkaian aktivitas pembelajaran kelas yang terintegrasi dalam suatu metode desain riset guna membantu mahasiswa dalam memahami integral. Tulisan ini membahas salah satu aktivitas tentang jumlah Rieman, limit dan luas untuk melihat apakah kesulitan mahasiswa dalam meng-koneksikan sigma, area dan definisi integral secara geometri dengan menggunakan pendekatan pendidikan matematika realistik (PMRI).

Pemilihan pendekatan PMRI dikarenakan karakteritik dari pendekatan ini yang diharapkan mampu mengatasi permasalahan yang ter jadi.(Tasman, 2017) menyatakan lima karak teristik dari pendekatan PMRI yang diaplikasikan dalam penelitian ini. Yaitu 1) Konstruksi ide dimulai dari situasi yang dipahami oleh mahasiswa. Penelitian ini tidak dimulai dari level formal yang bersifat abstrak, tetapi dimulai dari situasi yang dipahami oleh mahasiswa sehingga pembelajaran menjadi bermakna bagi maha siswa. 2) Pengembangan matematika dari konkrit ke abstrak, dimana pengetahuan informal 
mahasiswa yang berasal dari pengalaman mereka digunakan dalam proses pembalajaran untuk membangun suatu konsep pengetahuan tentang integral. 3) Mendorong mahasiswa untuk bebas mengeluarkan ide dan refleksi dalam proses pembelajaran. 4) Didorongnya aktifitas sosial dengan adanya interaksi dalam pembelajaran baik antar mahasiswa maupun dosen pengampu mata kuliah dengan mahasiswa. 5) Keterkaitan antara satu topik dengan topik yang lainnya. Kelima karakteristik ini diharapkan dapat mampu mendorong mahasiswa untuk dapat membangun pengetahuan mereka tentang topik integral khususnya hubungan sigma, luas dan definisi integral.

\section{METODE PENELITIAN}

Desain Riset dipilih sebagai metodologi penelitian. Pemilihan desain riset sejalan dengan pendapat (Edelson, 2002) yang menyatakan tiga keunggulan dari desain riset, yaitu 1) Menyediakan perspektif yang produktif tentang perkembangan teori. 2) Memiliki karakteristik khusus yaitu hasilnya yang dapat langsung dimanfaatkan. 3) Secara langsung dapat melibatkan peneliti dalam upaya peningkatan pendidikan. Lebih jauh lagi, menurut (Bakker, 2004)Desain riset memiliki lima karakteristik keunggulan. Pertama adalah tujuan dari desain riset adalah mengembangkan teori dan strategi yang di desain untuk dapat mendukung pembelajaran. Dalam penelitian ini, peneliti mendesain suatu intruksional teori untuk mahasiswa dalam melihat hubungan antara sigma, area dan definisi integral. Kedua, intervensi yang diberikan dalam desain riset bersifat natural. Metodologinya membuat peneliti untuk tidak terkendala dalam memperbaikki desain setelah eksperimen dilaksanakan. Ketiga, desain riset memiliki prospektif dan refleksi terhadap komponen, komponennya yang tidak dapat terpisahkan dari pelaksanaan eksperimen. Peneliti akan dihadapkan kepada dugaan-dugaan sebagai suatu prospektif dengan pembelajaran sebenarnya yang di observasi pada bagian refleksi. Keempat, proses siklus dari desain riset memunculkan temuan dan revisi yang bersifat iteratif. Kelima, teori dari desain riset ini, relatif sederhana dalam hal bagaimana ia dikembangkan untuk suatu domain khusus dimana dalam penelitian ini, peneliti ingin mengembangkannya dalam domain Kalkulus khususnya bagian definisi integral.
(Bakker, 2004) juga menyatakan bahwa tujuan utama dari desain riset adalah mengembangkan teori beserta intruksional materi dimana teori tersebut dibandingkan untuk mengevaluasi teori dan materi pembelajaran.

Desain riset yang digunakan pada penelitian ini, terdiri atas tiga tahap, yaitu:

1. Tahap persiapan (Desain)

Tahap ini dimulai dengan mengidentifikasi tujuan pembelajaran, yang dikombinasikan dengan rencana-rencana yang telah disiapkan untuk menghadapi kendala yang mungkin terjadi dalam mencapai tujuan. Hasil dari dugaan-dugaan tersebut adalah intruksional material yang terdiri atas tiga bagian yang disarikan dari (Gravemeijer, 2004). Tiga komponen tersebut yaitu: a) Tujuan pembelajaran bagi mahasiswa. b) Rencana untuk instruksional yang akan diberikan yang juga mencakup alat dan bahan yang akan digunakan. c) Dugaandugaan dalam proses pembelajaran. Hal ini bertujuan untuk memahami mahasiswa berfikir dalam berfikir dan memahami permasalahan ketika kegiatan dilaksanakan.

2. Tahap pelaksanaan di kelas

Pada tahap ini, instruksional material yang telah dirancang dicobakan, direvisi, dievaluasi dan dicobakan kembali. Tahaptahap evaluasi yang dilakukan antara lain:

a) Evaluasi sendiri (self-evaluation), yaitu peneliti mengevaluasi sendiri desain yang telah dirancang dengan menggunakan daftar cek dari karakteristik atau spesifikasi desain. b) Tinjauan ahli (expert review), yaitu untuk melihat validitas produk yang dihasilkan dengan meminta pendapat ahli yang berkaitan untuk memberikan penilaian dan saran-saran terhadap desain. Pada proses ini dilihat tingkat validitas desain.

c) Evaluasi satu-satu (one-to-one evaluation), yaitu dengan meminta sasaran pengguna desain yaitu seorang dosen dan mahasiswa untuk menilai desain tersebut. Dilanjutkan dengan mewawancarai responden. d) Evaluasi kelompok kecil (small group evalution), yaitu meng gunakan desain kepada sekelompok kecil pengguna. Selanjutnya pengguna diberikan angket untuk memberi penilaian dan masukan terhadap desain. e) Uji lapangan (field test), yaitu menggunakan desain pada pembelajaran pada satu kelas peserta didik. Selanjutnya, dilihat tingkat kepraktisan 
produk yang dikembangkan. Akan tetapi, dalam proses pengujian di kelas ekperimen, desain yang dirancang Dalam tahap pelaksanaan digunakan untuk mengujikan aktifitas instruksional. Setelah itu direvisi kegiatan instruksional untuk menciptakan lokal instruksional teori terhadap bagaimana beberapa kegiatan instruksional dapat bekerja.

3. Retrospektif analisis

Tahap ini, semua data yang telah didapatkan dianalisis. Hypothetical Learning Trajectory (HLT) atau dugaan-dugaan dalam proses berfikir mahasiswa, dibandingkan dengan kenyataan yang didapatkan. Sehingga dapat memciptakan suatu Local Instructional Theory (LIT) seperti yang digambarkan dalam Gambar 1 berikut.

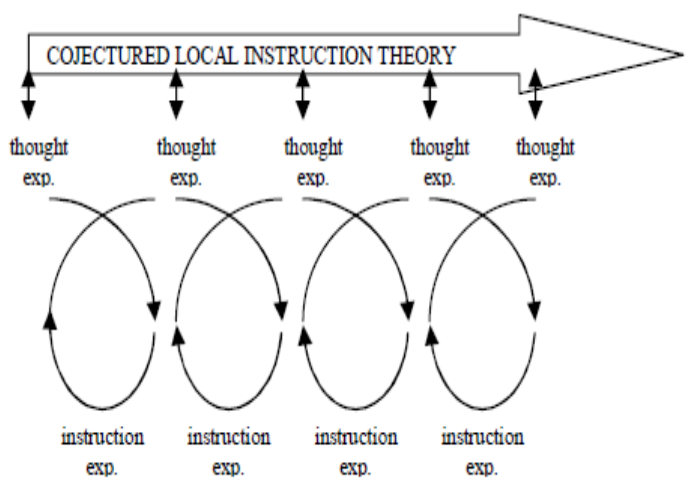

Gambar 1. Proses Siklik dari Desain Riset (Gravemeijer, 2004)

Subjek penelitian adalah 30 orang mahasiswa tahun pertama di Jurusan Matematika, Fakultas Matematika dan Ilmu Pengetahuan Alam Universitas Negeri Padang. Data penelitian didapatkan melalui video, lembar kerja mahasiswa dan catatan lapangan yang dikumpulkan selama tahap pelaksanaan di kelas. Aktivitas mahasiswa dan strategi yang mereka gunakan akan diobservasi dari video. Interview juga dilakukan untuk meningkatkan validitas data penelitian.

\section{HASIL DAN PEMBAHASAN}

Hasil dan pembahasan dibatasi pada tahap evaluasi satu-satu yang telah dipaparkan pada bagian metodologi. Pada tahap persiapan, materi tentang defenisi integral di analisis. Analisis dilakukan dilihat dengan melihat silabus mata kuliah, buku teks kalkulus, wawancara dengan dosen kalkulus serta wawancara dengan siswa.
Berdasarkan hasil analisis, maka dirancang suatu instruksional material yang terdiri atas tiga bagian yaitu: 1) Tujuan Pembelajaran. Tujuan pembelajaran yang akan dicapai adalah mahasiswa dapat memahami definisi integral secara geometri. 2) Rencana untuk kegiatan instruksional. Pada tahap ini, direncanakan mahasiswa akan diberikan permasalahanpermasalahan untuk membangun pemahaman mereka tentang definisi integral. 3) Dugaandugaan dalam pro-ses pembelajaran. Dengan instruksional material yang telah dirancang, mahasiswa diduga dapat memahami koneksi antara sigma, area dan luas integral.

Setelah instruksional material selesai dirancang, maka dilakukanlah self validation dan dilanjutkan dengan expert validation. Setelah dua hal tersebut dilakukan maka dilakukanlah evaluasi satu-satu kepada dosen Kalkulus dan seorang mahasiswa. Artikel ini, akan difokuskan pada hasil evaluasi satu-satu yang dilaksanakan dengan salah seorang mahasiswa.

Instruksional material yang dirancang dimulai dengan pemahaman mahasiswa tentang luas, dimana diharapkan dengan instruksinal tersebut mahasiswa dapat memahami bahwa untuk menghitung luas permukaan suatu objek dapat dilakukan dengan membaginya menjadi daerah-daerah kecil (unit) yang dapat dihitung luasnya, kemudian luas permukaan objek dapat di ketahui dengan menjumlahkan unit-unit tersebut. Setelah itu, mahasiswa diperkenalkan dengan notasi sigma dan sifat-sifat notasi sigma. Mahasiswa diberikan contoh permasalahan tentang notasi sigma dan diberikan penjelasan tentang sifat-sifat notasi sigma. Kemudian mahasiswa diberikan permasalahan tentang jumlah Rieman dalam topik poligon dalam dan poligon luar. Mahasiswa diharapkan dapat menggunakan pengetahuan mereka tentang sigma dalam memecahkan persoalan tentang poligon dalam dan poligon luar serta diharapkan mereka dapat memahami perbedaan kedua pendekatan tersebut. Setelah itu, diharapkan mahasiswa dapat memahami terdapat hubungan antara nilai limit yang yang diambil dari jumlah Riemann dengan luas daerah dan definisi integral. Secara singkat tujuan pembelajaran matematika yang dirancang dapat dilihat dalam Gambar 2. 


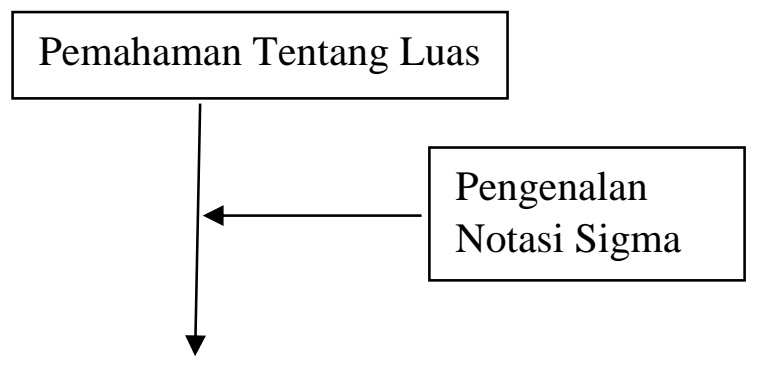

Pemahaman Tentang Jumlah Riemann
(Poligon Dalam dan Poligon Luar)

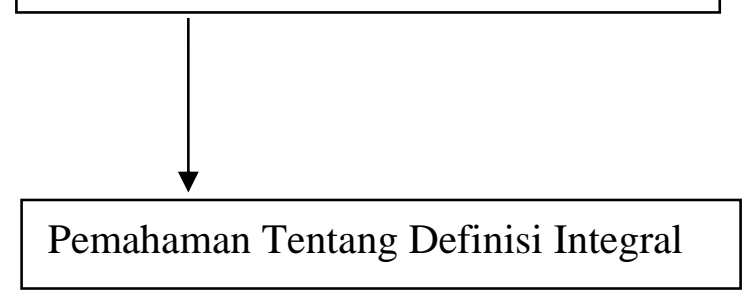

Gambar 2. Rancangan Tujuan Pembelajaran Matematika

Pada intruksional material yang dirancang. Untuk memahami tentang luas, mahasiswa diperkenalkan tentang unit dan diminta untuk membuat hubungan luas suatu bangun datar dengan menggunakan bangun datar yang lain dan mereka diminta mengisi blanko kosong yang telah disediakan. Permasalahan tersebut dapat dilihat pada Gambar 3 berikut.

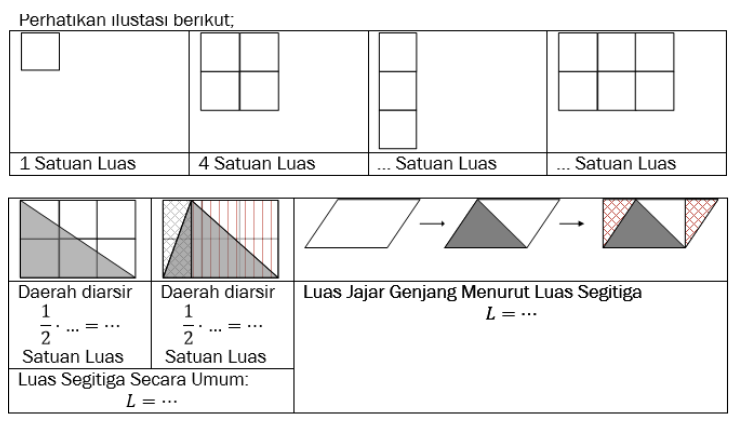

Gambar 3. Permasalahan Memahami Luas

Ketika permasalahan ini, dicobakan kepada salah seorang mahasiswa, mahasiswa tersebut dapat menyelesaikan permasalahan tersebut dengan baik. Ia menjawab dengan unit satuan dan jawabannya benar. Akan tetapi, ketika diminta untuk membandingkan dengan luas segitiga, jawaban mahasiswa tersebut masih dalam satu satuan unit. Artinya mahasiswa tidak dapat melihat langsung hubungan luas jika dibandingkan dengan luas bangun yang lain dari instruksional material yang telah dirancang. Namun melalui wawancara, mahasiswa dapat menjawab dengan baik dengan memahami bahwa luas suatu bangun datar dapat dihampiri dengan bangun datar lainnya. Sehingga dari kegiatan wawancara yang dilakukan peneliti mendapatkan ide untuk memperbaiki permasalahan yang diberikan.

Setelah mahasiswa memahami bahwa luas suatu bangun dapat dihampiri dengan luas bangun datar lainnya, mahasiswa diharapkan memahami bahwa hampiran dapat diperbaiki sehingga nilainya dapat semakin dekat dengan nilai sebenarnya. Maka untuk itu mahasiswa diberikan penjelasan seperti Gambar 4.

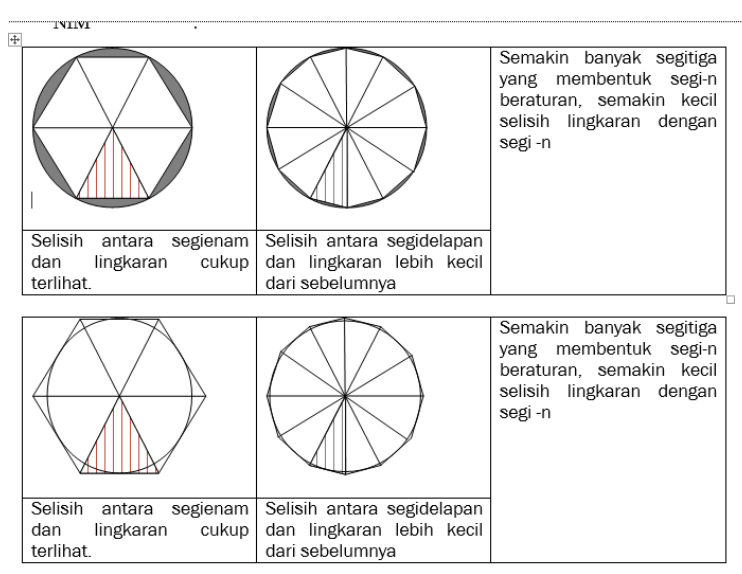

Gambar 4. Penjelasan Tentang Hampiran Luas

Ketika penjelasan tentang hampiran ini diberikan kepada mahasiswa, mahasiswa memahami maknanya dengan baik. Berikut transkrip wawancara peneliti $(\mathrm{P})$ dengan Mahasiswa (M).

P : Coba Ananda baca dan perhatikan ilustrasi ini (Menujuk penjelasan seperti pada gambar 4)

M : Baik Pak!

$\mathrm{P}$ : Apa yang ananda pahami dari penjelasan pada ilustrasi tersebut?Apa yang ananda dapat jelaskan dari pemahaman ananda setelah membaca ilustrasi tersebut?

M : Luas lingkaran dapat dihampiri dari luas poligon pak, semakin banyak sisi poligon yang dibuat hampiran akan semakin bagus.

P : Apa yang ananda maksud dengan semakin bagus?

M : Luas poligon semakin dekat dengan luas lingkaran sebenarnya pak!

P : Bagaimana ananda tahu tentang hal tersebut?

M : (Menunjuk gambar pojok kiri atas) bapak bisa lihat bahwa di sebelah sini ada selisih luas lingkaran dengan luas poligon. Ketika sisi poligon bertambah maka selisih tersebut 
semakin kecil (menunjuk gambar kanan atas).

Dari transkrip tersebut dapat di ketahui bahwa mahasiswa telah memahami bahwa hampiran akan semakin bagus jika segi-n bertambah. Hal ini merupakan bagian penting dalam proses pembelajaran tentang definisi integral yang harus dilalui oleh mahasiswa ketika belajar integral, karena pengenalan integral secara geometri yang berarti luas daerah di bawah kurva mengambil konsep limit yang menuju tak berhingga yang idenya sama dengan hal tersebut.

Setelah mahasiswa memahami tentang luas, bahwa luas permukaan suatu bagun dapat dihampiri dengan menggunakan luas yang lain. Mahasiswa diberikan penjelasan tentang sigma, sifat-sifat sigma dan beberapa soal latihan tentang sigma. Sehingga mahasiswa mengenal tentang teorema sifat-sifat sigma yang dapat dilihat seperti Gambar 5.

\section{TEOREMA SIFAT-SIFAT NOTASI SIGMA}

Misalkan $c$ suatu konstan, maka
$\sum_{i=1}^{n} i=1+2+3+\cdots+n=\frac{n}{2}(n+1)$
$\sum_{i=1}^{n} i^{2}=1^{2}+2^{2}+3^{2}+\cdots+n^{2}=\frac{n(n+1)(2 n+1)}{6}$
$\sum_{i=1}^{n} i^{3}=1^{3}+2^{3}+3^{3}+\cdots+n^{3}=\left(\frac{n(n+1)}{2}\right)^{2}$
$\sum_{i=1}^{n} i^{4}=1^{4}+2^{4}+3^{4}+\cdots+n^{4}=\frac{n(n+1)(2 n+1)\left(3 n^{2}+3 n-1\right)}{30}$

Gambar 5. Teorema Sifat-sifat Sigma

Sifat-sifat sigma yang terdapat dalam Gambar 5 sangat penting untuk dipahami mahasiswa sebagai pengetahuan awal untuk dapat menyelesaikan permasalahan tentang jumlah rieman. Sehingga, jika mahasiswa tidak memahami tentang sifat-sifat tersebut maka dapat dipastikan mereka akan mengalami kesulitan dalam memahami hubungan atau koneksi antara sigma, luas dan definisi integral. Pada bagian pengenalan notasi sigma ini, umumnya, mahasiswa dapat memahami sifatsifat tentang notasi sigma. Akan tetapi, masih terdapat beberapa kesalahan perhitungan yang dilakukan. Hal ini biasanya terjadi dalam proses penyederhanaan perhitungan sehingga dida patkan hasil yang salah.

Setelah mahasiswa paham dengan sigma berserta sifat-sifatnya, pembelajaran difokuskan pada pemahaman tentang jumlah Riemann. Pengetahuan tentang luas yang telah mereka dapatkan diharapkan dapat membantu mahasiswa bahwa mereka dapat menghitung suatu luas bangun datar dengan membaginya menjadi beberapa bangun bangun datar yang lain. Sehingga pembelajaran tentang jumlah Riemann dimulai dengan menghitung luas daerah di bawah kurva. Mahasiswa diminta melukis daerah yang dibatasi oleh kurva $y=x^{2}$, garis $x=2$, dan sumbu$\mathrm{x}$. Karena pengetahuan yang baik tentang fungsi, mahasiswa dapat melukis daerah tersebut yang dimaksud. Gambar 5 memperlihatkan bagaimana jawaban mahasiswa yang diwawancarai.

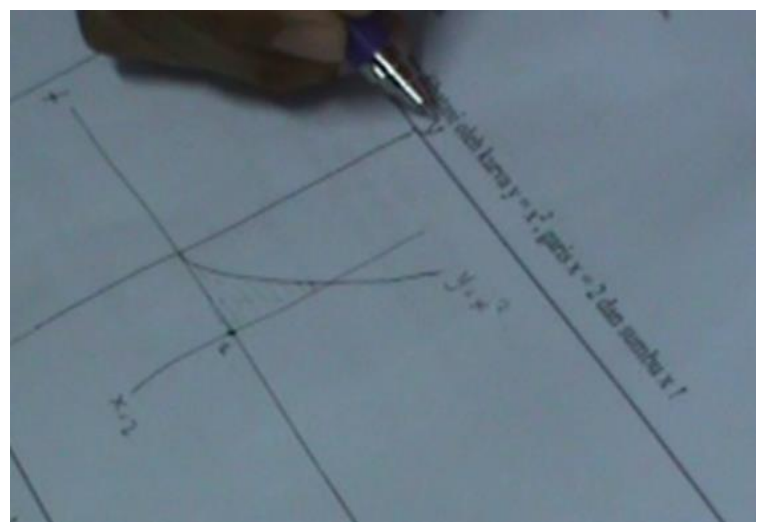

Gambar 5. Jawaban Mahasiswa Tentang Daerah yang Terbentuk

Berikut transkrip wawancara dengan mahasiswa.

P : Mana dia daerah yang dibatasi oleh sumbu yang dimaksut?

M : (Menunjuk Gambar 5 yang telah ia lukis) ini dia pak!

$\mathrm{P}$ : Sumbu-x nya mana?

$\mathrm{M}$ : (menulis $\mathrm{x}$ di ujung kiri garis sumbu-x) ini pak!

$\mathrm{P}$ : Sumbu-y nya mana?

$\mathrm{M}$ : (menulis y di bagian atas garis sumbu y) ini pak!

$\mathrm{P}$ : Mana luasnya ini ?

M : Ini pak (sambil mengarsir daerah tertutup yang dihasilkan)

P : O, itu luasnya, Sekarang jika bapak tanya, bagaimana cara $\mathrm{M}$ menghitung luas itu?

M : Dibagi-bagi pak !

$\mathrm{P}$ : Coba bagaimana cara membaginya ?

M : Dibagi pak, dibagi kayak gini pak ! (sambil melukis dengan mempartisi alas menjadi beberapa bagian)

Gambar 6 memperlihatkan hasil lukisan mahasiswa ketika ia membagi daerah luas menjadi beberapa bagian. 


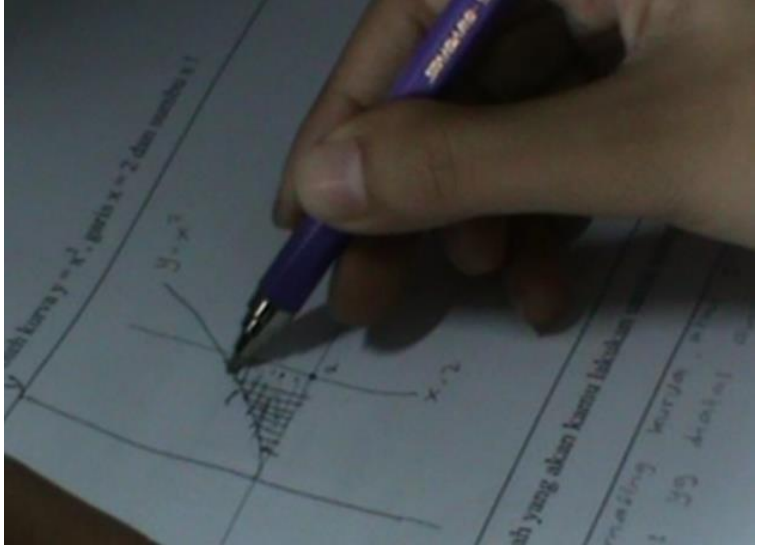

Gambar 6. Partisi Daerah Luas

Dari ilustrasi Gambar 6 tersebut, dapat dilihat pemahaman mahasiswa tentang makna luas membawa suatu pengetahuan awal yang bagi mahasiswa untuk memahami tentang jumlah rieman. Cara partisi mahasiswa tersebut pada akhirnya akan membawa kepada $\int d x$ karena partisinya secara vertikal, partisi lain yang mungkin muncul adalah partisi secara horizontal yang membawa kepada $\int d y$.

Ketika mahasiswa diminta menuliskan langkah-langkah menghitung luas, mahasiswa tersebut menjawab tidak tahu. Hal tersebut wajar, karena ia, belum belajar tentang jumlah Riemann. Untuk itu, mahasiswa ditanya apakah gambar daerah yang ia lukis sama dengan gambar daerah yang diberikan yang dapat dilihat pada Gambar 7 berikut.

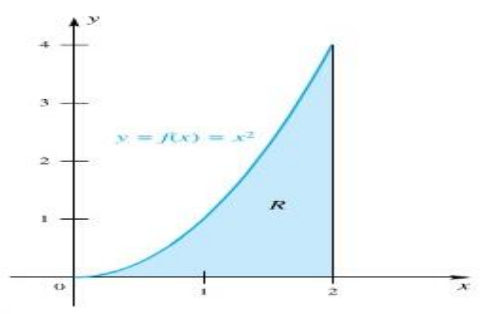

Gambar 7. Luas Daerah Yang Terbentuk

Mahasiswa mengalami sedikit kesulitan ketika memaknai bahwa daerah yang ia lukis dibagi secara vertikal, maka itu juga berarti ia membagi alas dari daerah tersebut menjadi beberapa bagian. Maka pemberian ilustrasi pembagian alas seperti yang dapat dilihat pada Gambar 7 menjadi suatu bagian penting bagi mahasiswa.

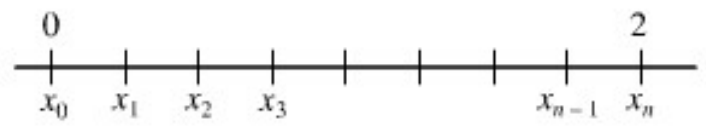

Gambar 7. Partisi Alas
Garis partisi alas tersebut sangat penting ditunjukkan pada mahasiswa karena $\mathrm{x}_{0}$ sampai $\mathrm{x}_{\mathrm{n}}$ akan memberikan informasi tentang berapa bagian daerah yang dihitung ingin dibagi. Jika dibagi 20 itu berarti $x_{n}$ adalah 20. Lalu panjang partisi alas juga merupakan bagian penting pada bagian ini. Umumnya, mahasiswa mengalami kesulitan untuk menentukan nilai dari $\mathrm{x}_{\mathrm{i}}$. Mereka harus memahami bahwa alas dipartisi sama besar sehingga panjang $\Delta \mathrm{x}$ yang diberikan adalah sama. Sehingga untuk permasalahan ini, $x_{i}$ adalah $2 \mathrm{i} / \mathrm{n}$ yang diperoleh dari panjang $\Delta \mathrm{x}$ adalah sebesar $2 /$ n dan dikalikan dengan i karena $x_{i}$ akan berada pada posisi I, yang disebabkan pangkal garis yang dibagi adalah 0. Akan tetapi, apabila pangkal dari segmen alas yang dibagi tidak lagi 0 , mahasiswa mulai menghadapi kesulitan untuk memahami hal tersebut.

Selain itu, partisi tersebut juga akan memperlihatkan berapa tinggi yang akan dipakai dalam membuat dugaan luas yang akan dihitung seperti yang ditunjukkan oleh Gambar 8 berikut.
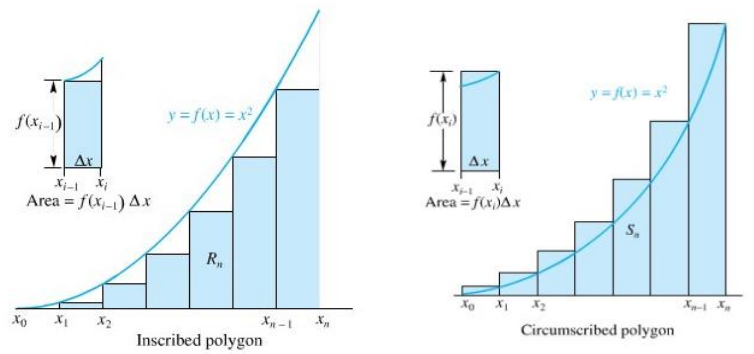

Gambar 8. Pendekatan Hampiran Luas

Pada saat ilustrasi seperti Gambar 8 diberikan, mahasiswa sedikit kesulitan untuk memahami 2 gambar tersebut. Hal ini sangat wajar, karena ilustrasi tersebut memiliki banyak hal penting yang harus mereka perhatikan. Salah satunya adalah tinggi poligon. Mahasiswa sedikit kesulitan kenapa tinggi poligon untuk bagian poligon dalam dinyatakan dengan $\mathrm{f}\left(\mathrm{x}_{\mathrm{i}-1}\right)$ dan $\mathrm{f}\left(\mathrm{x}_{\mathrm{i}}\right)$ untuk poligon luar. Dalam hal ini, pengetahuan mahasiswa tentang fungsi akan menjadi penting. Mereka harus memahami bahwa jika nilai fungsi yang diberikan adalah berarti tinggi poligon yang dilihat.

Setelah melalui proses diskusi dan mahasiswa dapat memahami tentang mengapa tinggi dapat dituliskan dalam fungsi, mahasiswa diminta untuk memperhatikan 2 gambar yang merupakan salah satu potongan poligon yang terdapat pada gambar 8. Gambar tersebut dapat dilihat pada Gambar 9. 

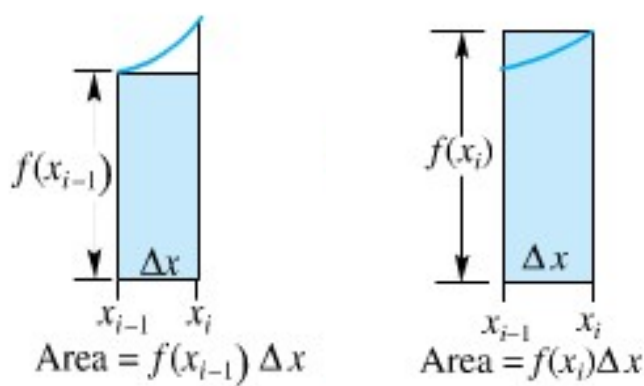

Gambar 9. Perbedaan Poligon Dalam dan Luar

Pemahaman akan perbedaan poligon dalam dan luar, sangat penting sekali bagi mahasiswa. Akan tetapi, jika mahasiswa tidak memiliki pengetahuan yang cukup tentang nilai suatu fungsi dan luas persegi panjang, maka hal ini akan sulit dipahami bagi mahasiswa. Mahasiswa yang diujikan melihat bahwa tinggi poligon dalam adalah $\mathrm{f}\left(\mathrm{x}_{\mathrm{i}-1}\right)$ karena ia dapat melihat bahwa tinggi poligon adalah yang di sebelah kiri dimana $\mathrm{x}$-nya adalah $\mathrm{x}_{\mathrm{i}-1}$ sehingga itu berarti tingginya adalah $\mathrm{f}\left(\mathrm{x}_{\mathrm{i}-1}\right)$ sedangkan untuk yang poligon luar ia melihat bahwa tingginya adalah yang di sebelah kanan. Dimana saat itu $\mathrm{x}$ nya adalah $x_{i}$ sehingga tingginya adalah $f\left(x_{i}\right)$. Dari ilustrasi tersebut ia juga dapat melihat bahwa luasnya daerah yang dimaksud akan lebih besar dari poligon dalam dan akan lebih kecil dari poligon luar.

Bagian berikutnya adalah bagaimana cara menghubungkan luas poligon satuan dengan luas seluruh poligon. Hal ini menyebabkan mahasiswa harus dapat melihat bahwa tinggi poligon selalu berubah sementara alasnya tetap (karena dibagi menjadi $\mathrm{n}$ bagian yang sama) sehingga luas keseluruhan dapat dinyatakan dengan

$$
A\left(R_{n}\right)=f\left(x_{0}\right) \Delta x+f\left(x_{1}\right) \Delta x+f\left(x_{2}\right) \Delta x+\cdots+f\left(x_{n-1}\right) \Delta x
$$

untuk poligon dalam dan

$$
A\left(S_{n}\right)=f\left(x_{1}\right) \Delta x+f\left(x_{2}\right) \Delta x+\cdots+f\left(x_{n}\right) \Delta x
$$

untuk poligon luar.

Kedua formula tersebut dapat menjadi hal yang sulit dipahami mahasiswa ketika mereka belum memahami tentang perbedaan poligon dalam dan luar.

Setelah mahasiswa memiliki pemahaman yang kuat tentang formula tersebut, bagian tersulit berikutnya untuk mereka pahami adalah menghitung total luas yang didapatkan. Jika banyak partisi alas diberikan maka mahasiswa dapat dengan mudah menghitung hampiran luas yang berupa angka (bilangan). Akan tetapi, yang diinginkan dari belajar jumlah Riemann adalah mahasiswa perlu untuk membuat formula umum dalam suatu persamaan dalam n. Jika mahasiswa memiliki pemahaman yang baik tentang notasi sigma, maka hal ini tidak lagi menjadi suatu permasalahan. Sebagai contoh, mahasiswa yang di wawancarai mengetahui dengan baik sifat-sifat sigma yang telah ia pelajari, sehingga ia dapat dengan mudah menghampiri luas yang dimaksud dengan persamaan dalam $\mathrm{n}$.

Jika mahasiswa dapat menghampiri luas daerah dalam $n$, maka selanjutnya bagaimana integral dapat berarti luas daerah di bawah kurva menjadi suatu bagian yang penting. Mahasiswa harus memahami hubungan apabila $\mathrm{n}$ diganti dengan suatu bilangan, maka persamaan luas dalam $n$ yang sudah mereka temukan berarti luas poligon sebanyak yang akan terbentuk. Hal ini tidak dapat dilihat secara aljabar sehingga mahasiswa yang diujikan tentang permasalahan ini akan mengalami kesulitan memahami hal tersebut. Untuk itu, sejalan dengan pendapat (Reis, 2010) yang menyatakan bahwa Geogebra dapat membantu hal tersebut. Sehingga, secara ilustrasi dapat diperlihatkan kepada mahasiswa seperti Gambar 10.
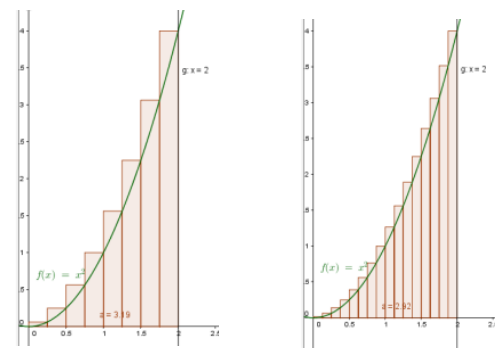

Gambar 10. Ilustrasi Geogebra Jika $\mathrm{n}=8$ dan $\mathrm{n}=15$

Gambar 10 memperlihatkan poligon luar yang terbentuk jika alasnya dibagi menjadi delapan bagian yang sama dan 15 bagian yang sama.

Selanjutnya, fitur slider yang terdapat dalam Geogebra, membantu memberikan visualisasi kepada mahasiswa bahwa semakin banyak partisi alas akan semakin baik hampiran yang diberikan dan jika limit partisi alasnya diambil menuju tak berhingga maka hal tersebut akan berarti luas daerah di bawah kurva. Atau secara matematis dapat dinyatakan dengan

$$
\lim _{\|P\| \rightarrow 0} \sum_{i=1}^{n} f\left(\bar{x}_{i}\right) \Delta x_{i}
$$

Sehingga hal ini dapat membawa mahasiswa kepada definisi integral tentu yang berupa 


$$
\int_{a}^{b} f(x) d x=\lim _{\|P\| \rightarrow 0} \sum_{i=1}^{n} f\left(\bar{x}_{i}\right) \Delta x_{i}
$$

\section{KESIMPULAN}

Hasil penelitian menemukan bahwa dalam belajar tentang definisi integral tentu, mahasiswa memerlukan pengalaman belajar yang harus mereka alami. Diantaranya adalah pengalaman untuk memaknai luas, mengetahui sigma dan sifat-sifatnya serta definisi integral itu sendiri. Berdasarkan hasil evaluasi satu-satu yang dilakukan, maka dapat disimpulkan kesulitan mahasiswa dalam memahami integral tentu adalah mereka tidak dapat melihat dengan baik hubungan antara sigma, luas, dan definisi integral. Dalam hal ini, pengetahuan tentang sigma dan luas merupakan bagian yang tak terpisahkan dalam memahami definisi integral. Namun, mahasiswa masih melihatnya secara terpisah. Mahasiswa mengalami kesulitan dalam menginterpretasikan hasil perhitungan yang mereka dapatkan secara aljabar. Geometri memberikan pemaknaan beserta visualisasi dalam belajar tentang definisi integral. Untuk itu, penggunaan software matematika seperti Geogebra dalam pembelajaran matematika sangat dianjurkan.

Berdasarkan hasil evaluasi satu-satu yang dilakukan, maka dirasakan perlu untuk merancang suatu aktivitas pembelajaran yang lebih komprehensif sehingga dapat memberikan kesempatan kepada mahasiswa untuk berfikir matematis dalam memahami integral tentu dan dapat melihat koneksi antara, sigma, luas, dan definisi integral tentu sebagai suatu bagian utuh yang tidak dapat dipisahkan pada pembelajaran.

\section{DAFTAR PUSTAKA}

Bakker, A. 2004. Design research in statistics education: On symbolizing and computer tools.

Edelson, D. C. 2002. Design research: What we learn when we engage in design. The Journal of the Learning Sciences, 11(1), 105-121.

Gravemeijer, K. 2004. Local instruction theo-ries as means of support for teachers in reform mathematics education. Mathema-tical Thinking and Learning, 6(2), 105-128.

Mahir, N. 2009. Conceptual and procedural performance of undergraduate students in integration. International Journal of Mathematical Education in Science and
Technology, 40(2), 201-211.

Reis, Z. A. 2010. Computer supported mathematics with Geogebra. Procedia - Social and Behavioral Sciences, 9, 1449-1455.

Serhan, D. 2015. Students' Understanding of the Definite Integral Concept. Interna-tional Journal of Research in Education and Science, 1(1), 84-88.

Tasman, F. 2017. Supporting Second Graders' on Learning Multiplication. BahnhofstraBe 28, 66111 Saarbrucken, Germany: Lambert Academic Publishing.

Tasman, F., \& Ahmad, D. 2017. Pemahaman Mahasiswa Terhadap Integral Sebagai Anti. Eksakta Pendidikan, 1(1), 9-16.

Tasman, F., \& Ahmad, D. 2018. Visualizing Volume to Help Students Understand the Disk Method on Calculus Integral Course. IOP Conference Series: Materials Science and Engineering, 335, 012112.

Zakaria, Effandi \& Salleh, T. S. 2016. Using Technology in Learning Integral Calculus. Mediterranean Journal of Social Sciences , 6(6), 144-148. 